PETER E. QUINT

\title{
The Border Guard Trials and the East German Past- Seven Arguments
}

\section{INTRODUCTION}

In the years following German unification, the courts have conducted criminal trials of former East German officials for reprehensible actions committed under the old regime. The most notable of these are the trials of eastern border guards-as well as Politbüro members and other high officials-for their roles in the use of deadly force to prevent eastern citizens from escaping over the border into West Berlin or the Federal Republic of Germany.

Although these prosecutions raise a number of complex difficulties, certainly the central issue evokes a problem that was also confronted at Nuremberg after World War II: Can officials of a dictatorial regime be convicted of reprehensible acts that may have been legal under the laws of that regime-without violating the principle of non-retroactivity, the principle that a person may not be convicted of a criminal offense unless that offense was established by law at the time the act was committed. In the case of German unification, this problem is rendered particularly acute by the inclusion of the non-retroactivity principle in Article 103(2) of the German Basic Law (Constitution). The principle is also reflected in the Unification Treaty, which was adopted when the German Democratic Republic (GDR) joined the Federal Republic.

In the case of many of the shootings at the Berlin Wall, it was at least strongly arguable that the acts were legal under East German

Peter E. Quint is Jacob A. France Professor of Constitutional Law, University of Maryland School of Law.

Revised version of a lecture delivered at the $22^{\text {nd }}$ Annual Conference of the German Studies Association, Salt Lake City, Utah, October 10, 1998. This essay develops certain themes previously discussed by the author in The Imperfect Union: Constitutional Structures of German Unification (1997); and "Judging the Past: The Prosecution of East German Border Guards and the GDR Chain of Command," 61 Review of Politics 303 (1999).

For valuable comments on an earlier draft of this essay, the author is grateful to Richard Boldt, Gregg O. Kvistad, Stanley Paulson and William Reynolds. The author also wishes to thank participants in the Law \& Politics Colloquium of the Political Science Department, Johns Hopkins University, and members of the Institute for Philosophy and Public Policy, University of Maryland College Park, where several of the ideas in this paper were presented and discussed. 
law. The GDR Border Law of 1982 allowed the use of deadly force in the case of felonies at the GDR border, and many unauthorized border crossings could have been categorized as felonies under East German statutes.

Notwithstanding this substantial problem, many border guards have been convicted in the German courts for the shootings at the GDR border. Moreover, in recent trials, officials of the GDR hierarchy-including some former members of the Politbüro-have been convicted for their role in the fatal border regime. In order to justify these results, some courts have reached back to an idea set forth by the German legal philosopher Gustav Radbruch, in an article published shortly after World War II. ${ }^{1}$ In this article Radbruch emphasized that the non-retroactivity principle is a very strong principlebut in the end, only one principle of justice among others. Accordingly, Radbruch argued that even the non-retroactivity principle might have to yield to stronger demands of justice in certain extraordinary cases-those cases in which the inconsistency between the non-retroactivity principle and other requirements of justice has reached an "unbearable degree." 2

Radbruch seemed to believe that this relativization of the nonretroactivity principle would probably only be justifiable as a response to the Nazi regime or comparable circumstances. ${ }^{3}$ The German courts, however, have used intervening human rights instruments in order to fill out the "Radbruch formula" and apply it to criminalize the shootings at the East German border. In particular, the courts have invoked the International Covenant on Civil and Political Rights, which contains a right to life as well as a qualified right of individuals to leave any country including their own.

In an alternative argument, German courts have also tried to satisfy the non-retroactivity principle by arguing that even the law of the GDR itself-when that law is "properly" interpreted-would have criminalized many uses of deadly force at the East German border; hence the punishment of these actions now should not be considered retroactive. In this argument, the present courts have "interpreted" GDR law according to principles that seem more consistent with

1. Radbruch, "Gesetzliches Unrecht und übergesetzliches Recht," 1 Süddeutsche Juristen-Zeitung 105 (1946), reprinted in Arthur Kaufmann (ed.), 3 Gustav Radbruch Gesamtausgabe (1990) at 83.

2. "The conflict between justice and legal security can be resolved by saying that the positive law . . . will have priority even when it is unjust or unsuitable [unzweckmäßig] unless the contradiction between the positive law and justice reaches such an unbearable degree that the statute-as 'incorrect law'-must give way to justice." Id. at 89. Except as otherwise noted; all translations in this essay are those of the author.

3. Radbruch, "Gesetz und Recht," reprinted in 3 Gesamtausgabe 96, 99. See Paulson, "Radbruch on Unjust Laws: Competing Earlier and Later Views?," $150 x$ ford Journal of Legal Studies 489, 497 (1995). 
West German legal theory than the theory actually employed in the GDR. Through the use of these arguments, many former border guards have been convicted, but they have generally received suspended sentences. Significant prison terms, however, have been imposed on higher officials. ${ }^{4}$

\section{The Border Guards Cases: Seven Arguments}

Notwithstanding the confidence with which they are often advanced, the arguments in these cases-as well as the related discussions of some commentators-frequently exhibit confusing ambiguities. Indeed, there seem to be at least seven separate arguments-in the German judicial opinions and in the works of Radbruch and others-that might be asserted to establish criminal liability in the border guards cases. In this essay I will try to set out the distinct arguments as clearly as possible, and briefly examine the implications of each-in the hope that such an analysis can lead to a better understanding of these issues. The arguments run along a spectrum from a frank recognition of permissible retroactivity-a position that I call the "strong" Radbruch argument-at one extreme, to the argument that certain actions were clearly and undeniably illegal under GDR law (and therefore present punishment is not retroactive), at the other. Furthermore, it may be argued that-for reasons relating to the nature of the GDR or the special circumstances of German unification-the entire non-retroactivity principle is not important in this context.

In thinking about these arguments for criminal liability, two general points should be borne in mind: First, in the relevant German opinions these arguments are not always kept clearly separate; indeed, two or more of them frequently overlap, and they are sometimes employed without clear distinction in the same opinion. Second, even within these arguments there are some possible variations, and therefore the total number of arguments is probably greater than seven; but for purposes of coherence, I have sometimes thought it best just to note possible variations within the statement of an individual argument itself.

The possible arguments for criminal liability are as follows:

\section{First Argument: The "Strong" Radbruch Argument.}

Even if the action was legal at the time it was committed, the action was so reprehensible that justice allows (or requires) us to penalize that action now. Therefore, present penalization is retroactive, but this is an instance in which retroactive penalization is justified because superior princi-

4. See generally Quint, "Judging the Past," 61 Review of Politics, at 304-08. 
ples of justice outweigh the principle of non-retroactivity. In deciding whether an action was so reprehensible that the principle of non-retroactivity is outweighed in this manner, the general rules of international law may help in making the determination. ${ }^{5}$

I call this the "strong" Radbruch argument because it relies on what is clearly a judgment today about what happened in the past; it involves no attempt to find that the acts were actually illegal under the law of the prior regime. Thus this argument candidly calls for retroactive law-making, but it seeks to justify retroactivity in some circumstances. With Radbruch, this argument assumes that the nonretroactivity principle is a very strong principle and that it should ordinarily prevail, but that in some extraordinary instances it may be outweighed by other principles of justice. Under this argument, the appropriate punishment of very evil acts-the shootings at the GDR border-marks one of the circumstances in which the non-retroactivity principle is appropriately outweighed.

It seems doubtful, however, whether Radbruch himself would have approved the application of this formula to the cases of GDR criminality. Radbruch believed that the non-retroactivity principle

5. A recent statement of this argument appears in an opinion of the German Constitutional Court upholding the convictions of a border guard and members of the National Defense Council, a leadership group of the GDR, for their roles in the border regime. 95 BVerfGE 96 (1996). In this opinion, the Court declared:

"[The holders of GDR state power] were implementing extreme governmental injustice, which can only maintain itself as long as the state power that is responsible for [that injustice] in fact continues to exist. II In this extremely unusual situation, the command of substantive justice (which also includes observance of human rights recognized in international law) prohibits the application of [the defense available to the border guards under written and unwritten GDR law.] The strict protection of reliance, [contained in] Article $103(2)$ of the Basic Law, must yield. Otherwise, the criminal law of the Federal Republic would come into conflict with its own premises of the rule of law. ..."

Id. at 133; cf. note 52 infra. See also 39 BGHSt 1, 14-16 (1992).

A similar argument was invoked by German courts in applying Control Council Law No. 10, penalizing war crimes and crimes against humanity, in the early postwar period. In finding that a brutal Nazi prison guard was guilty of crimes against humanity, for example, the Supreme Court for the British Zone stated:

"That Control Council Law No. 10 to a certain extent punishes actions that, at the time of their commission, were not declared to be punishable does not militate against [the law's] applicability. . . . [Retroactive punishment of crimes against humanity] is not unjust, and therefore a German judge should not feel burdened in his conscience in applying the rule. Retroactive punishment is unjust when the act, at the time of its commission, not only did not violate a positive rule of the criminal law, but also did not violate the moral law [Sittengesetz]. That cannot be said in the case of crimes against humanity. In the view of all morally sensitive people severe injustice was committed, the penalization of which would have been a duty under the rule of law. The retrospective correction of that dereliction of duty, through retroactive punishment, is in accordance with justice."

1 OGHSt 1, 4-5 (1948). 
was so important that it could be discarded only under the most extreme circumstances and, as noted above, he remarked that probably only the actions of the Nazi regime, or enormities of comparable scope, would qualify for this purpose. This argument, therefore, raises the question of whether the deadly border policy, in the context of other actions of the GDR, is comparable to the acts of the Nazi regime. ${ }^{6}$

I believe that it is not comparable, principally for three reasons.

First, the hundreds of persons shot or otherwise killed at the GDR border (more than 200 but probably less than 1000) pale by comparison with the millions of persons killed by the Nazi regime. It seems to me that, under any measure, such a disparity in the numbers is important. ${ }^{7}$

Second, the nature of the intent possessed by the GDR actorswhile clearly sufficient in some contexts to create criminal liabilityis different from and, I would argue, represents a lesser degree of evil than the type of intent possessed by many Nazi actors. The border guards, as well as the higher GDR officials, had what is referred to in German criminal law as "limited intent" (bedingter Vorsatz). In contemplating the use of force at the border, their primary goal was to prevent persons from leaving the GDR. They "accepted" the distinct possibility, in any given case (and the certainty overall), that persons would be killed in trying to escape. Yet they would have been as happy (in most cases, even happier) if no one tried to escape and no one were killed.

The intent of many Nazi actors was quite different. Their ultimate intent was to kill certain classes of people, and they intended to do so regardless of what persons in those classes did. Thus, if any given individual in the GDR stayed in his or her house and went to his or her job, and did not come close to the border, none of the GDR actors would intend to kill that person. On the contrary, a person

6. See Imperfect Union at 204-05.

7. See, e.g., Ralf Dreier, Juristische Vergangenheitsbewältigung (1995) at 17: "[T]he parallel with the Third Reich [is] inappropriate. Certainly: the GDR radically limited the freedom of its citizens and systematically suppressed political opposition. ... It established a comprehensive system of [internal] espionage and ruined the life-chances of countless people. It practiced a border policy that cost the lives of several hundred people. But in [the GDR] millions of people were not killed solely on the basis of their membership in a particular race, and [the GDR] did not wage a war of aggression in which 60 million people were killed." See also id. at 33.

For a contrasting view, however, see 1992 JZ 691, 693 (LG Berlin, Decision of Jan. 20, 1992)(trial court judgment in an early border guards case): "[Prior court decisions involving Radbruch's formula and similar views] indeed were developed as a result of the crimes of the National Socialist injustice-regime in Germany-which in the monstrousness of their scale are not comparable with the circumstances being considered here. Nonetheless, the court has no doubts about following these decisions in this case also; for the protection of human life has a general validity and cannot depend upon the occurrence of a specified number of homicides." 
doing precisely the same things under the Nazi regime would be the subject of the Nazis' intent to kill, if that person fell into one of the specified classes. Again, this is not to deny that the GDR officials could have possessed adequate criminal intent by virtue of their understanding that shootings at the Wall were likely to involve death; it is also not to deny that the intent possessed by the border guards and officials was reprehensible; it is rather to argue that the degree of evil in that intent is considerably less than in the intent possessed by the Nazi actors.

Third, in large part, the intent of the Nazi actors was an intent to eradicate persons of a certain race, religion, or ethnic origin-thus, an intent to destroy entire cultures. As the prototype of what came to be known as genocide, this type of intent to kill has generally been seen as even more reprehensible than an intent to kill certain persons under other circumstances. ${ }^{8}$ There was no comparable intent in the GDR border guards cases.

Even if it is acknowledged (as most German scholars do indeed acknowledge) that the actions of the GDR are not comparable to those of the Nazi regime, it still has been argued that the GDR actions at the border were sufficiently reprehensible to justify overriding the principle of non-retroactivity through use of the Radbruch formula, amplified by contemporary ideas of human rights as set forth in the U.N. human rights instruments. ${ }^{9}$ Whatever one concludes on this point, however, it seems likely that any such result would expand the area of the Radbruch formula beyond what Radbruch himself had in mind.

\section{Second Argument: Knowledge of Guilt and/or Knowledge that the Action Could be Subject to Later Punishment.}

Even if the action was legal at the time it was committed, the actor knew (a) that in some important sense the action was wrong, and/or (b) that the action could well be subject to later punishment. Because of this knowledge, present penalization is not unjust. Under this argument present penaliza-

8. Convention on the Prevention and Punishment of the Crime of Genocide, Dec. 9, 1948, 78 U.N.T.S. 277. On this point, see Karl Jaspers, "Für Völkermord gibt es keine Verjährung," in Wohin treibt die Bundesrepublik (10 $0^{\text {th }}$ ed. 1988) at 26-27: "Genocide means basically the execution of a judgment over another human group-over a people-that it shall not live on the earth. Whoever calls for such a judgment and carries it out is a criminal against humanity ... [N]o person has the right to make the judgment that a people should not exist. [Whoever carries out such a judgment in an organized mannerl does something that is fundamentally different from all crimes of the past. . Administrative mass murder [is] an entirely new crime, without example in history." See also Hannah Arendt, Eichmann in Jerusalem: A Report on the Banality of Evil (rev. ed. 1977), at 267-79 ("These were 'crimes' different not only in degree of seriousness but in essence.")

9. See, e.g., Robert Alexy, Mauerschützen. Zum Verhältnis von Recht, Moral und Strafbarkeit (1993) at 22-30. 
tion may be retroactive, but the underlying theory of the nonretroactivity principle is not violated. The non-retroactivity principle seeks to enhance security by preserving reasonable expectations of non-penalization, but here there was no reasonable expectation that the actions would not be penalized eventually. In any case, the principle should not protect a person who knew that his actions were wrong.

As indicated, this argument comes in two distinct but related variations. According to the first variation, the actor possessed an internal sense of guilt and knew at the time that he should not have committed the act, even though it may have been legal at the time. Because of this sense of guilt and the actor's internal knowledge that he should not have committed the act-the argument contends-it is not unjust to punish the actor now, notwithstanding any reliance on non-prosecution that he might have had as a result of the legality of the act under the positive law of the time. ${ }^{10}$

The second variation is somewhat more complex. In this variation, the actor knows or suspects that he may ultimately be subject to punishment under another legal regime-by a later occupying force, or an international tribunal-notwithstanding the possible legality of the act under the domestic law applicable at the time. Under this variation of the argument, it is not unjust to punish the actor now because-even if he committed the act completely without feelings of guilt-he knew or suspected that he might be subject to subsequent punishment, and that knowledge or suspicion makes his reliance on the positive law less than a reasonable reliance. ${ }^{11}$ Of course, the two variations of the argument may be combined: the actor felt guilt for the act at the time and, because of his recognition of the enormity of the act, feared or suspected that he might be subject to later punishment under a different regime.

For this argument to count as a separate justification of retroactive punishment, it probably should involve an individual determination of the mental state of the defendant in each case. It is sometimes argued that the acts were so dire that the defendant "must have felt a

10. See n. 20, infra; cf. 2 BGHSt 234, 238-40 (1952) (guilty knowledge as element of the offense).

11. See, e.g., Kaufmann, "Die Radbruchsche Formel vom gesetzlichen Unrecht und vom übergesetzlichen Recht in der Diskussion um das im Namen der DDR begangene Unrecht," $1995 N J W$ 81, 84-85: "Article 103(2) of the Basic Law is above all directed toward the protection of reliance. Couldn't the [border guards] at least suspect that at some point they would be called to account?" See also 95 BVerfGE at 134; 51 VVDStRL at 121 (remarks of Eckart Klein): "[T]he controlling organs of the GDR were aware how significantly they deviated from the fundamental beliefs of the rest of the world, outside of the communist bloc. ... Moreover, the Germans in the east shared with the West Germans the experience of official injustice during the Nazi period. They were no longer in a state of innocence." A version of the same argument was also employed by the Nuremberg Tribunal. See Nazi Conspiracy and Aggression: Opinion and Judgment (1947) [Nuremberg Judgment] at 49. 
sense of guilt" or "must have known that he would be subject to later punishment." But when these formulations are employed-with nothing more-there is often little to distinguish this argument from the "strong" Radbruch argument: if a court finds that the acts are sufficiently serious to override the principle of retroactivity, the court may also infer that the acts are so serious that they were known by the defendants to be wrong; and, conversely, perhaps the acts must approach the Radbruch boundary to justify drawing the inference of guilty knowledge with the necessary degree of assurance. More interesting, however, are the situations in which an inference of this kind is employed with other evidence for the purpose of drawing conclusions as to the actual state of mind of the defendants.

In determining whether the actors knew that the action was wrong and-particularly - that the non-retroactivity principle might not be preserved, it would be possible to take into account not only the reprehensible nature of the action and other factors, but also whether various warnings were given during the time of the dictatorial regime. For example, during World War II the Allies issued a number of statements making clear that Nazi war crimes and other atrocities would be punished at the conclusion of the war. ${ }^{12}$ Moreover, during the Cold War period the West German government took actions that in effect constituted similar warnings to the GDR-such as collecting information on human rights abuses in a central archive in the western town of Salzgitter.

From an historical point of view, this is one of the more interesting of the arguments because it opens up the question of what the GDR officials were actually thinking. This argument may also re-

12. See, e.g., Sadat Wexler, "The Interpretation of the Nuremberg Principles by the French Court of Cassation: From Touvier to Barbie and Back Again," 32 Colum. J. Transnat'l L. 289, 301-03 (1994) (discussing St. James Declaration of 1942 and Moscow Declaration of 1943). See also Henry T. King, Jr. (ed.), Nuremberg Revisited: The Judgment of Nuremberg in Today's World (1970) at 8: “. . . I feel only pity for the [casuist] who will dismiss the Nazi leaders because 'they were not warned it was a crime.' They were warned, and they sneered in contempt." (Remarks of Adrian Fisher, quoting former Secretary of War Henry L. Stimson).

For a related argument in the specific context of the Nuremberg Judgment, see Luban, "The Legacies of Nuremberg," 54 Social Research 779, 805 (1987) (footnotes omitted):

"[W] hy did Himmler order all traces of the death camps to be removed? Why did Goebbels boast in September 1944 that he was number one on the Allied list of war criminals? And once it is admitted that the Nazis knew that what they were doing would be supremely hateful to the Allies, the objection that they did not expect to be held criminally liable becomes unimportant. For their legitimate expectation was that they would be summarily shot. The plain conclusion is that [Nuremberg prosecutor Robert] Jackson was right: if the Nuremberg defendants' expectations were violated, it is because they received better treatment than they had any reason to expect. Since what is wrong with retroactive law is that it gives people worse treatment than they had reason to expect, it follows that the Nuremberg trial, though based on retroactive law, did not wrong its defendants." 
quire a focus on the clash between contending world views: the world view of nations or institutions which condemn the actions-and may be giving the warnings-and the world view of the actors, such as members of the GDR hierarchy, who apparently believed that the cruel actions at the border were necessary to preserve socialism (as they saw it), a belief that may have militated against a sense of guilt.

An important aspect of this argument could focus on the numerous actions taken by GDR officials to conceal the shootings at the Wall or other deaths at the border. Special instructions, for example, sharply limited the use of force at the border on the occasion of important international visits to Berlin or similar festive occasions-when a shooting at the Wall might attract unfavorable attention. ${ }^{13}$ When a victim was shot at the border, every attempt was made to conceal the wounded or dead person from the view of western border guards. ${ }^{14}$ Victims were frequently taken to special police hospitals instead of regular hospitals (sometimes with substantial delays and risks to the health and life of the victim); ${ }^{15}$ officials were required to file certificates falsely stating that nothing out of the ordinary had occurred on the evening in question; ${ }^{16}$ certificates were sometimes falsified to indicate death from natural causes ${ }^{17}$ or relevant documents were destroyed; ${ }^{18}$ and relatives were sometimes not informed of the true cause of death. ${ }^{19}$

Arguably, all of these phenomena could be ascribed to a sense of guilt for these actions, or at least to an understanding that they violated international norms and therefore might be subject to later punishment. ${ }^{20}$ Acceptance of this view could mitigate the importance of strict enforcement of the non-retroactivity principle, along the lines described above.

Yet the question is a difficult one because there are other possible explanations. Even without a sense of guilt or wrongdoing, the GDR officials responsible for such policies could understand that these actions might damage the (purely) political position of the GDR

13. See, e.g., 39 BGHSt 1, 13; 39 BGHSt 168, 190 (1993).

14. See, e.g., 42 BGHSt 356, 359 (1996); 39 BGHSt 1, 12.

15. 39 BGHSt 1, 12.

16. Id.

17. Cf. 39 BGHSt 168, 173.

18. Id.

19. See, e.g., 95 BVerfGE at 119. See also 40 BGHSt 218, 222 (1994).

20. See, e.g., McAdams, "Communism on Trial: The East German Past and the German Future," in A. James McAdams (ed.), Transitional Justice and the Rule of Law in New Democracies (1997) at 247: "As the judge stressed in his ruling lin the first border guards trial], the defendants themselves had shown in their testimony that they had known what they were doing was wrong. They admitted that they had routinely done everything they could to maintain the secrecy of [the] shootings . . . after the fact." See also Starck, "Der Rechtsstaat und die Aufarbeitung der vorrechtsstaatlichen Vergangenheit," 51 VVDStRL 9, 18 (1992): "This secrecy was the result of the bad conscience of the rulers." 
in international relations, and they might have sought to conceal these actions for that reason. (Perhaps in the view of the GDR officials such actions made the GDR appear weak.) Furthermore, the officials may have feared that knowledge of these actions within the GDR population might lead to further discontent. ${ }^{21}$

Needless to say, these questions of belief may be very difficult to determine. In order to assess the strength of this argument, it could be important to understand which motivations (or mixture of motivations) played an actual role. In any case, this argument seems to apply more strongly to higher officials who made these policies than to the border guards who carried them out. Yet perhaps it could also be argued that the border guards' knowledge of these acts of concealment could be taken into account in determining whether the guards themselves knew that the shootings were in some way criminal or in violation of international norms.

\section{Third Argument: General Principles of Justice Overrode Formal Law Even Then.}

Even if the action was formally legal under the law of the prior regime, the action was so reprehensible that it was not truly legal even then, because it violated general principles of justice which overrode positive law at the time. Therefore, present penalization is not retroactive, because superior principles of justice overrode the formal law even then. ${ }^{22}$

21. Moreover, GDR leaders sometimes asserted their belief that the maintenance of the closed border was required by geo-political necessity. For example, in his speech before the criminal court in Berlin, Erich Honecker advanced the following claim: "From my point of view, neither the Basic Treaty, nor Helsinki, nor German unification would have come to pass if the Wall had not been built then or if it had been torn down before the end of the Cold War. Therefore I believe that neither I nor my comrades assumed any legal guilt, nor indeed any political or moral guilt, when I said yes to the Wall and stuck to that position." Honecker argued that, if the Wall had not been built, a continuing outflow of citizens would have provoked further intervention by the Soviet Union with the risk of a Third World War. Uwe Wesel, Der Honecker-Prozeß: Ein Staat vor Gericht (1994) at 75-76. Whether or not one accepts Honecker's political analysis on this point, these words may have accurately represented his beliefs and state of mind.

22. This position is frequently stated in the modern German cases. See, e.g., 41 BGHSt 101, 105: "Punishment [under these circumstances] would not conflict with Article 103(2) of the Basic Law. For the [border guards' legal] defense-in view of the clarity of the injustice incorporated in it-would never have become effective"; see also id. at 112; 39 BGHSt 1, 22 (statute as applied in the GDR was invalid from the outset). For a similar position in the post-Nazi jurisprudence, see 2 BGHSt 234, 23839 (1952): "Regulations that do not even seek justice, that intentionally renounce the concept of equality and clearly disregard the legal beliefs common to all cultured peoples ... do not create law ..."

This position may also be suggested by a second proposition contained in Radbruch's famous article. See nn. $1 \& 2$, supra. After stating the proposition set forth in note 2 -which is generally referred to as the "Radbruch formula"-Radbruch continued: "It is impossible to draw a sharper line between the cases of statutory injustice, and those statutes that are nonetheless valid in spite of their incorrect content [un- 
In theory, this argument differs from argument (1)-the "strong" Radbruch argument-because this argument posits that general principles of justice overrode positive law at the time that the act was committed. The "strong" Radbruch argument, in contrast, does not assert that the law was changed by superior principles of justice at the time the act was committed, but rather acknowledges that those principles are being applied in a retroactive or retrospective manner by today's legal system.

Yet an initial question that is raised by this argument is whether it actually differs much from the strong Radbruch argument as a practical matter. The answer to this question may depend upon one's view of the nature of the principles of justice that override the nonretroactivity principle. If these principles of justice are thought to be eternal and immutable-the same for all times, regions, and circumstances - then there may seem to be little practical difference between this argument and argument (1): if the principles of justicewhich are eternal-are sufficient to override the principle of non-retroactivity at the time of the trial, then the same eternal principles would probably have been adequate to override the positive law at the time that the actions were taking place.

On the other hand, if one believes that the applicable principles of justice might vary according to different circumstances (for example, in accordance with changing views of general principles of international law), then it might be conceivable that external principles of justice might override positive law at one time, but not perhaps at another. ${ }^{23}$

But even in those instances in which the practical effects of arguments (1) and (3) may be similar, it seems to me that (1)-the "strong" Radbruch argument-is the preferable argument, because it makes clear that it is actually the present legal system that is allowing the "positive" law to be overridden by disregarding the nonretroactivity principle. The equation of arguments (1) and (3) tends to obscure the differences between the relevant legal systems as to the possibility of "overriding". Generally speaking, dictatorial legal systems, such as that of the GDR, do not allow positive law to be overridden by general ideas of human rights; this is an operation of the contemporary legal system. Unlike argument (3), therefore, ar-

richtigen Inhalt]. But another border-line can be drawn quite sharply: where justice is not even aspired to, where equality-which constitutes the core of justice-is intentionally renounced in the setting down of positive law, in such a case the statute is not even 'incorrect law'; rather it completely lacks the nature of law." 3 Gesamtausgabe at 89 .

23. Cf. Kaufmann, supra n. 11, at 86: according to Radbruch's view, the content of "natural law" could change according to time and place; Paulson, supra n. 3, at 49899; cf. also Horst Dreier, "Gustav Radbruch und die Mauerschützen," 1997 JZ 421, 425-26: certain views of human rights in customary international law may have been accepted in the $1980 \mathrm{~s}$, but not in 1972 when a particular border guards case arose. 
gument (1) does not impute to a prior legal system a method of argument, and a source of law, that were not actually employed in that system. ${ }^{24}$

\section{Fourth Argument: Principles of International Law Overrode Domestic Law Even Then.}

Even if the action was legal under the domestic law of the prior regime, the action was ultimately not legal even then, because it violated applicable rules of international law which overrode domestic law at the time. Therefore, present criminalization is not retroactive because superior principles of international law overrode domestic law even then.

This argument differs from argument (3) because here it is not the general principles of justice (or natural law) that are said to have overridden positive law in the past; rather, domestic law has been superseded by the "positive" principles of international law as they existed at the time.

In the context of the border guards cases, this argument could rest on the premise that the shootings at the Wall violated Article 12(2) of the International Covenant on Civil and Political Rights, which grants every person a right to leave any country, including his or her own. Of course, this right of exit is subject to certain exceptions set forth in Article 12(3) of the Covenant-including exceptions for "national security" and "public order." According to this argument, however, these exceptions may apply only to unusual cases and not to a general refusal to allow egress, such as that practiced by the GDR. Moreover, the shootings might also violate Article 6 of the Covenant, prohibiting the arbitrary deprivation of human life. ${ }^{25}$

24. In 1990, in the final year of the GDR, the highest court of East Germany began to participate in the legal revolution by applying generally democratic and western principles of law to questions of "rehabilitation" of certain persons who had been oppressed under the GDR. See Imperfect Union at 218; Laskowski, "UnrechtStrafrecht-Gerechtigkeit. Die Probleme des Rechtsstaats mit dem DDR-Unrecht," $1994 J A$ 151-52. Suppose that, at that time, the GDR courts themselves had also begun to re-interpret GDR law in a manner that resulted in criminal penalization of border guards. How should those cases have been treated? Would that have been seen as a "natural" development in the criminal law of a legal system, or would it be viewed as so great a change in the interpretation of the criminal law-to the disadvantage of the criminal defendant-that it was essentially the same as the imposition of retroactive punishment? Cf. 92 BVerfGE 1 (1995) (Nötigung Case). If so, penalization under these circumstances would have required justification under one or more of the arguments reviewed here.

25. On these points, see 39 BGHSt 1, 16-23.

On the question of arbitrary deprivation of human life, there is a possible parallel in American constitutional law. See Tennessee v. Garner, 471 U.S. 1 (1985). In this case, the Supreme Court found that it is a Fourth Amendment violation for a police officer to use "deadly force to prevent the escape of an apparently unarmed suspected felon," unless the use of deadly force "is necessary to prevent the escape and the officer has probable cause to believe that the suspect poses a significant threat of death or serious physical injury to the officer or others." Id. at 3. Although only civil liabil- 
For cases arising before the effective date of the 1966 Covenant, courts have also found that the shootings violate similar provisions of the Universal Declaration of Human Rights (1948). ${ }^{26}$ On the other hand, the shootings at the Wall probably do not constitute "crimes against humanity" as first set forth in section 6(c) of the Nuremberg Charter. Under subsequent interpretations, "crimes against humanity" seem to be limited to violent and aggressive actions taken in a massive and systematic manner or in furtherance of racial, religious or political discrimination. Indeed, some German scholars maintain that the current view of crimes against humanity does not externd beyond offenses contained in the Genocide Convention of 1948, which certainly does not cover actions like those of the border guards. ${ }^{27} \mathrm{An}$ eminent German authority has also noted that since it is not even certain that Articles 12 and 6 of the 1966 Covenant were violated by the shootings at the border, "it can scarcely be assumed that the more stringent criteria of a crime against humanity were fulfilled."28

In certain general respects, argument (4) may encounter greater difficulties than argument (3), because this argument involves a shift from the workings of certain natural law ideas-present in arguments (1) and (3)-to an argument that may depend more clearly on the law of the state in question, including its views on the applicability and effect of international law.

The precise relationship between international law and the domestic law of a state remains a highly complex question, with a variegated set of responses. To a great extent, that relationship depends upon rules adopted by the state itself, and those rules are likely to distinguish between the effect of customary international law and the effect of treaties. Some states, for example, are willing to apply certain treaties directly as internal law. But certain other nations hold that no treaty may form a part of domestic law until it has been

ity-rather than a criminal prosecution-was at issue in this case, the decision was cited by the German court. See 39 BGHSt at 20-21.

26. See 40 BGHSt 241, 244-49 (1994).

27. Polakiewicz, "Verfassungs- und völkerrechtliche Aspekte der strafrechtlichen Ahndung des Schusswaffeneinsatzes an der innerdeutschen Grenze," 1992 EuGRZ 177, 181-82; Laskowski, supra n. 24, at 161. See also Gornig, "Die Verantwortlichkeit politischer Funktionsträger nach völkerrechtlichem Strafrecht," 1992 NJ 1, 8-10 (Crimes against humanity currently seem limited to genocide and apartheid).

28. Alexy, supra n. 9, at 20; see also Laskowski, supra n. 24, at 159-61 (doubts about violation of 1966 Covenant). But for a different view, see Blumenwitz, "Zur strafrechtlichen Verfolgung Erich Honeckers," 1992 DA 567, 575-77. On this problem, see generally Orentlicher, "Settling Accounts: The Duty to Prosecute Human Rights Violations of a Prior Regime," 100 Yale L.J. 2537, 2587-95 (1991) (The core principle of law relating to crimes against humanity is the punishment of massive atrocities).

The GDR Constitution and statutes did appear to incorporate certain rules of international law - including a prohibition of crimes against humanity - into the domestic law of the GDR. See Verf. DDR (1974) arts. 8, 91; StGB-DDR § 95. But the German courts have found that none of these provisions is applicable in the case of the GDR border guards. See 39 BGHSt 1, 18-19, 28-29. 
"transformed" into domestic law by domestic legislation. In contrast, many domestic systems tend to be somewhat more receptive to the general principles of international law than they are to treaties. ${ }^{29}$

In the United States, for example, the Supreme Court has held that the general rules of international law are automatically part of the law of the United States, except to the extent that they are altered or abrogated by statute or other authoritative legal rule. ${ }^{30}$ On the other hand, treaties of the United States are not always part of the domestic legal system: some treaties are "self-executing," and they form part of domestic law without further legislative action; ${ }^{31}$ other treaties, however, are not self-executing, and they do not form part of domestic law until they have been transformed into domestic law through statute. ${ }^{32}$ Indeed, in its resolution of advice and consent, the United States Senate declared that rights set forth in the Covenant on Civil and Political Rights are not "self-executing" within the United States. ${ }^{33}$ The Covenant's provisions may therefore have no effect on domestic law until transformed or adopted into domestic law by federal statute.

In requiring legislative approval of international treaties, the law of the GDR seems to have gone somewhat beyond that of the United States. Article 51 of the GDR Constitution required that the parliament (Volkskammer) approve international treaties to the extent that those treaties would amend laws of parliament. ${ }^{34}$ The GDR signed the International Covenant on Civil and Political Rights in 1974, and the Covenant went into effect in 1976. As noted above, Articles 12 and 6 of the Covenant might have altered the existing legal regime by making the shootings at the Wall no longer justified. Yet, the GDR parliament never enacted a statute transforming those rules of the Covenant into domestic law, as required by Article 51. The failure of the GDR parliament to have done so might be fatal to the argument that international law annulled any domestic legal justification for the shootings at the Wall, at the time that the shootings took place. ${ }^{35}$

29. For discussion of these issues, see, e.g., I.A. Shearer, Starke's International Law (11 ${ }^{\text {th }}$ ed. 1994) at 63-78.

30. The Paquete Habana, 175 U.S. 677 (1900). The Federal Republic of Germany goes a step further: under Article 25 GG, the "general rules of international law are part of federal law," and, moreover, they "have priority" over the domestic statutes.

31. Asakura v. Seattle, 265 U.S. 332 (1924).

32. See, e.g., Sei Fujii v. California, 38 Cal.2d 718, 242 P.2d 617 (Supreme Court of California 1952) (United Nations Charter).

33. 138 Cong. Rec. S4781, S4784 (Apr. 2, 1992).

34. Verf. DDR (1974) art. 51.

35. See, e.g., Dannecker, "Die Schüsse an der innerdeutschen Grenze in der höchstrichterlichen Rechtsprechung," 1994 Jura 585, 590-91 (A violation of the 1966 Covenant cannot lead to criminal liability of GDR border guards because "Article 103(2) of the Basic Law only takes into account the norms of positive law," and al- 
Yet it is clear that some rules of international law are so strong that they independently create crimes in international law which could be tried by international (or other) tribunals, totally apart from the domestic law of the state in which the acts occurred. Indeed such a position is clearly implied in the Nuremberg Judgment itself-in which international law rules were invoked to help satisfy the nonretroactivity principle, notwithstanding possible contrary rules of domestic law. ${ }^{36}$ Furthermore, the International Covenant on Civil and Political Rights itself recognizes that rules of international criminal law may supersede domestic rules. Article 15 (2) states that the nonretroactivity principle shall not "prejudice the trial and punishment of any person for any act or omission which, at the time when it was committed, was criminal according to the general principles of law recognized by the community of nations." 37

Along the same lines it might be possible to argue that, in some cases, the rules of international law on human rights are so strong that they override the failure of the domestic legal system to "transform" those rules into domestic law. The view of the contemporary German courts that international law rules may be taken into account in determining the guilt of the border guards-notwithstanding the failure of the GDR parliament to transform the Covenant into domestic law-seems to point in that direction. ${ }^{38}$

Yet it is clear that, in the present understanding of international law, not all international law rules give rise to directly enforceable actions of international criminal law or become immediately incorpo-

though the Covenant was ratified by the GDR, "it was never transformed into national law.") See also Alexy, supra n. 9, at 15-17.

36. In a crucial passage of its opinion, the Nuremberg Tribunal measured the language of its Charter against the rule of non-retroactivity and concluded that, by the time of World War II, international law had already criminalized aggressive war. Consequently, the Tribunal's enforcement of the Charter provision penalizing "crimes against peace" was not retroactive. In this discussion, the Tribunal does not even discuss the "legality" of the Nazi's acts of aggression under German domestic law. Rather, it is clear from the discussion that the international law rule, determining the illegality of aggressive war, would prevail regardless of the status of these acts under domestic German law of the Nazi period, or any other domestic law. See Nuremberg Judgment, pp. 48-53.

37. See also Universal Declaration of Human Rights art. 11(2). Article 7 of the European Human Rights Convention contains a similar provision. Interestingly, the Federal Republic of Germany entered a reservation to this section of the European Human Rights Convention, but not to the parallel provision contained in the International Covenant on Civil and Political Rights.

38. 39 BGHSt 1, 16-23. Cf. Hobe \& Tietje, "Government Criminality," 1996 German Yearbook of International Law 523, 542 (German Constitutional Court decision indicates that states "have lost the exclusive competence to determine how they incorporate international human rights into the national legal order"). For the use of international human rights principles by the Constitutional Court of Hungary in upholding a newly-enacted statute that provides criminal liability for acts committed during the Soviet suppression of the uprising of 1956, see Morvai, "Retroactive Justice based on International Law: A Recent Decision by the Hungarian Constitutional Court," East European Constitutional Review 32 (Fall 1993/Winter 1994). 
rated in domestic law without further action. Rather, only some of those rules give rise to directly applicable actions of international criminal law or become immediately applicable in domestic law by virtue of their international law status. In contrast, other rules of international law may continue to depend for their domestic application upon legislative activity in the individual states.

The question, then, is where the line is to be drawn between these two types of international law rules. The preferred view seems to be that only the "core" offenses of international criminal law-aggressive war, war crimes, crimes against humanity, torture, genocide-might create independent criminal actions or override rules of domestic law by virtue of their international law status alone. Other rules, even many of the rules contained in the International Covenant on Civil and Political Rights, probably remain dependent upon specific rules of domestic law in order to determine the extent to which they supersede the ordinary domestic law rules. In that case it would be difficult to argue that acts like the shootings at the borderwhich probably did not rise to the level of crimes against humanity ${ }^{39}$ or any of the other core international offenses-could be subject to criminal penalization under international law in a manner that would override the rules of the domestic legal system.

5. Fifth Argument: Non-Retroactivity Through Re-Interpretation of the Prior Law.

The action was so reprehensible that it was not even formally legal under the law of the prior regime: the domestic law of the prior regime, if properly interpreted, penalized the action at the time it was committed-even though, under the legal practice of the prior regime, the law was interpreted in a manner that did not penalize the action. Accordingly, present penalization is not retroactive because the law of the prior regime, when properly interpreted, penalized the action even then.

This argument plays a central role in the opinions of the German Supreme Court (the Bundesgerichtshof or BGH), the highest civil and criminal court in Germany. ${ }^{40}$ In these cases the court engaged in a course of interpretation that ran contrary to the theory and practice of the GDR and found that the relevant GDR statutes-when "correctly" interpreted-did not provide a justification for the shootings at the Wall. To reach this conclusion, the court invoked article $30(2)$ of the GDR Constitution which guaranteed each citizen's "personality and freedom." In the court's view, article 30(2) required that an individual's personality and freedom-which also included a right to

39. See text accompanying nn. 27-28, supra.

40. See 39 BGH 1, 22-30; 39 BGHSt 168, 184-85; 41 BGHSt 101, 105-06. 
life-could only be limited to the extent that the limitation is "unavoidable." The court also noted that, under the GDR Border Law, deadly force was only to be used as a last resort. Therefore, the court concluded, GDR law must be interpreted to include a principle of proportionality which would reject a defense for the intentional use of deadly force against an unarmed individual who was peacefully trying to cross the border.

In adopting this interpretation, the court ignored certain inconsistent provisions of the GDR Constitution, such as those emphasizing "socialist legality," a doctrine that allowed the views of the Communist Party to play a significant role in the interpretation of GDR law. In sum, the court determined that its own interpretationwhich was "friendly to human rights" and indeed basically tracked the western view of the these problems-was the "correct" interpretation of GDR law. Accordingly, the court found that, for purposes of Article 103(2)GG and the principle of non-retroactivity, the GDR law as so interpreted by the court was to be understood as the law actually in force at the time the act was committed. Since the existing GDR law (as re-interpreted by the court) did not justify the shootings at the Wall, the penalization of those acts today was found not to be retroactive. ${ }^{41}$

This argument confronts serious difficulties, because it involves an interpretation of past law which was radically different from the interpretation of the law actually employed in the legal system at the time. Indeed it seems to create an ideal law of the GDR that rather closely resembles West German doctrines. In the view of many, it involves an impermissible re-casting of the principles of GDR law in a manner that disregards the understanding of the legal system as it then existed, and constitutes a kind. of fiction adopted in order to avoid the problems of retroactivity. ${ }^{42}$

\section{Sixth Argument: Clear Violation of Prior Law.}

The action was so reprehensible that it was not even formally legal under the law of the prior regime; that law, under any plausible interpretation, penalized the action at the time it was committed. Therefore, present penalization is not retroactive because the law of the prior regime, in any plausible interpretation, penalized the action even then.

This argument, which only applies to a relatively small number of the border guard cases, is different from argument (5), because it does not require the extensive re-interpretation that is undertaken in (5). This argument posits that there are some cases in which even a

41. 39 BGHSt 1, 23-30; see Quint, supra n. 4, at 311-14.

42. See, e.g., Horst Dreier, supra n. 23, at 426-27; see generally Imperfect Union at 203; Quint, supra n. 4, at 312-13. 
mainstream lawyer or academic in the prior dictatorial regime would have been compelled to admit that a crime was committed under the law of that regime-even though (for corrupt reasons, or "reasons of state") the act may not actually have been prosecuted under the prior regime.

These instances are not as rare as one might imagine. In one case, for example, a border guard stopped an individual who was trying to flee across the border. After having immobilized the individual-so that there was no more chance that he could escape-the guard proceeded to shoot and kill the prisoner. No reasonable reading of the GDR statutes could yield a defense for this action, and it is difficult to imagine any kind of argument (even under the principles of the former regime) that could justify non-criminalization in this case. ${ }^{43}$

Theoretically, this argument might also prevail in less extreme circumstances. Section 27 of the Border Law of 1982, the GDR statute asserted as a defense in the border guard cases, furnishes a justification for the use of deadly force at the GDR border in some instances but not in others. For example, the statute generally required a warning before deadly force was used, and it only applied when the border crossing appeared to constitute a felony under GDR law. Consequently, in those cases in which no warning was given, or in which the crossing would clearly not have constituted a felony, the Border Law of 1982 might not provide a defense. ${ }^{44}$ Yet, because of the broad coverage of the felony offense for unauthorized border crossings, that particular avenue does not seem promising in most cases. ${ }^{45}$

A similar argument is available, perhaps, in the case of the GDR land mines. There may have been no statutory authorization for the installation of land mines at the GDR border-unlike the use of deadly force through shooting, for which section 27 of the Border Law furnished arguable statutory support. ${ }^{46}$ Accordingly, there may have been no exception from the general statute prohibiting murder and manslaughter. Yet this example raises more complex questions under this argument than the previous case of the particularly murderous border guard: these actions were authorized by votes of or-

43. These kinds of actions are sometimes referred to as "excesses" or "excess actions" in the German literature. See, e.g., Alexy, supra n. 9, at 21-22.

44. See Arnold, "Bundesverfassungsgericht contra Einigungsvertrag," $1997 \mathrm{NJ}$ $115,119$.

45. Under $\S 213$ of the GDR Criminal Code, the crime of "illegal border crossing" could constitute a felony if, among other things, the crossing was attempted in collaboration with others, or involved the use of a weapon or other "dangerous means or methods," or if it was performed "with particular intensity." See, e.g., Blumenwitz, supra n. 28 , at $574-75$.

46. See, e.g., Wesel, supra n. 21, at 140. 
gans such as the National Defense Council, and the legal status of such resolutions under GDR law would have to be determined. ${ }^{47}$

The foregoing six arguments can all be found-although perhaps not always in fully developed form-in the contemporary German decisions or literature, and in other important cases, such as the judgment of the International Military Tribunal at Nuremberg. The final argument, discussed below, is a more general argument about the weight of the non-retroactivity principle in light of the legal system of the GDR and the special circumstances of German unification. This argument is more difficult to find in the contemporary German literature although the argument may be suggested by a passage in the National Defense Council opinion of the Federal Constitutional Court. ${ }^{48}$ Indeed, an argument that calls into question the entire nonretroactivity principle in this context seems to cut very deeply against the grain of Article 103(2) of the Basic Law. Nonetheless, because of its theoretical importance, this argument will be discussed here.

\section{Seventh Argument: Disregarding the Non-Retroactivity \\ Principle in the Context of German Unification.}

Even apart from any countervailing principles of justice, the principle of non-retroactivity can itself be disregarded or discounted with respect to the offenses of GDR officials because (a) the GDR did not possess a true legal system with rules on which individuals could actually rely; or (b) even if the GDR did possess a legal system, the theoretical basis of the non-retroactivity principle does not require that the principle apply to the special case of German unification.

(a) It is often maintained by west German jurists that the GDR was an "injustice-state" (Unrechtsstaat). ${ }^{49}$ Perhaps this formulation is intended as an assertion that many or most of the legal rules enforced by the GDR legal system were, in substance, fundamentally unjust. But alternatively it could be. intended as an assertion that there were basically no binding legal rules applied by the GDR and that the courts acted at the unregulated will of the Communist Party and its officials. ${ }^{50}$ The first of these failings - the application of un-

47. For discussion, see, e.g., Arnold, supra n. 44, at 118-19. Cf. 95 BVerfGE at 100.

48. See note 52 , infra.

49. For discussion, see, e.g., Ralf Dreier, supra n. 7, at 14-18; Sendler, "Die DDR ein Unrechtsstaat-ja oder nein?," 1993 ZRP 1; Sendler, "Uber Rechtsstaat, Unrechtsstaat und anderes," 1991 NJ 379 . Indeed, the Unification Treaty itself uses the term "SED injustice-regime." Unification Treaty art. 17.

50. Cf. Sendler, $1991 \mathrm{NJ}$ at 380: "[An] essential characteristic of an injusticestate-[as] indeed has been remarked about the GDR-[is] that it was a system that 'didn't give a hoot about the law' [aufs Recht gepfiffen hat]". Of course, the formulation could refer to a mixture of these two failings, in various proportions. For exam- 
just rules-has been discussed in the context of Radbruch's formula. The second failing-the asserted absence of rules at all-remains to be considered here.

If a purported legal "system" consists only of decisions made according to the unguided will of officials, rather than according to some sort of legal rules or principles, it might be said that there was no legal system at all. If there were no patterns of rules or legal practices that could give rise to any reliance on the future actions of the government, then there could and would have been no reliance, in any event, on a principle of non-prosecution. If there had been no true legal system - and therefore no reliance-present prosecution by the Federal Republic after unification would not have placed the defendants in any worse position than they occupied under the wilful or whimsical practice of the GDR. Under these circumstances, it could be argued, the non-retroactivity principle can be left out of account.

The obvious problem with this sort of argument, however, is that there indeed were legal rules in the GDR, which-in a significant proportion of cases-seem to have been interpreted and applied according to principles or modes of reasoning that were not substantially different from those employed in the west. Although the knock on the door and the sudden disappearance in the night may have occurred under the Soviet occupation (and, perhaps also, in the early years of the GDR), such practices seem not to have been extensively employed in the final decades of the GDR's existence. Except in certain areas in which the Communist Party or the Stasi took a particular interest, there were rules upon which citizens could more or less rely. ${ }^{51}$ Moreover, in the specific context of the border guards cases, there were rules that could be interpreted to exonerate the border guards, and such an interpretation was clearly reflected in the practice under the GDR. Thus, from the point of view of the existence of the legal system giving rise to expectations, it seems difficult to argue-at least with respect to the defendants in these cases-that such a thing did not exist. 52

ple, it could be asserted that legal rules covered only some events in the GDR, and many of those legal rules were unjust. A possible third factor in this formulation could be the courts' application of rules that were known only to the courts and not to the population at large. Indeed, the GDR Supreme Court did sometimes issue secret instructions to the lower courts in certain politically sensitive areas of GDR law. See Inga Markovits, Imperfect Justice: An East-West German Diary (1995) at 24-27.

51. Indeed, the Unification Treaty-which regulated the "accession" of the GDR to the Federal Republic-generally accepted the results of GDR judicial and administrative actions, unless a violation of the rule of law was proven in the specific case. See Unification Treaty arts. 18-19; Laskowski, supra n. 24, at 155 . See generally 51 VVDStRL 158 (Denninger): "Of course the GDR was a state . . a state with a legal order . . . which we view today partially as injustice and partially as positive law."

52. In the National Defense Council case, the Constitutional Court found that, although the non-retroactivity principle is ordinarily absolute, it has diminished force in the case of the laws of the GDR-a country that "achieved neither democracy, nor 
(b) But even if we reject the proposition that the lack of a reliable GDR legal system made the non-retroactivity principle inapplicable-or at least weakened its authority-the fact that the GDR has now vanished as a polity after German unification might lead us to a similar conclusion. The principle of non-retroactivity has been seen as an important cornerstone of the rule of law for reasons referred to by Radbruch as "legal security." Where the principle does not obtain, a person may be prosecuted and penalized for actions that were not determined to be prohibited at the time the act occurred. The result is that people can live in constant terror, never knowing what actions may lead to prosecution, imprisonment, and even death. This constant state of terror is a hallmark of many dictatorial or totalitarian regimes; ${ }^{53}$ and it is this atmosphere of terror that the non-retroactivity principle is primarily intended to remove.

separation of powers, nor basic rights." 95 BVerfGE $96,132-33$ (1996). In the course of this discussion, the Court in effect notes that the GDR lacked the "special basis for reliance [possessed] by criminal statutes when they are issued by a democratic legislature that is bound by basic rights"-language suggesting that the people's diminished reliance on laws under the GDR may have contributed to the Court's weakening of the non-retroactivity principle. Id. at 133 . Yet a full reading of this difficult passage, in its context in the opinion, indicates that the Court's principal holding is that application of the non-retroactivity principle in order to give effect to practices that "gravely ignore human rights" runs contrary to the constitutional requirement of "substantive justice." Id. In other words the Court finally rests in this case on an application of the "strong" Radbruch principle (argument 1), perhaps as defined by the use of international human rights instruments. There may also be an undercurrent in this passage of the view-once a cornerstone of the foreign policy of the Federal Republic - that the GDR as an undemocratic government was lacking important elements of legitimacy. Cf. Quint, supra n. 4, at 324-29.

For a debate over the implications to be drawn from the existence of a lawless political party, "standing above the government and able at any time to interfere with the administration of justice whenever it does not function according to the whims of that power," see Lon L. Fuller, The Morality of Law (rev. ed. 1969) at 245-53 ("The Problem of the Grudge Informer").

53. For an example, see Anatoli Rybakov, Children of the Arbat (Harold Shukman trans. 1988), a novel written decades ago but first published in the Gorbachev era. In this novel, a dentist is called to repair Stalin's tooth at his villa in Sochi. Fearful that he will offend Stalin by some inadequacy in his work, the dentist fixes the tooth admirably, and he is allowed to spend some time on the beach near the villa. There he meets Kirov, a Communist Party official who-unknown to the dentist or to Kirov himself-was to be liquidated shortly thereafter. At the conclusion of his visit, Kirov mentions to Stalin that he met the dentist on the beach. As a result of these few words, Stalin orders that the dentist be removed from his position at the Kremlin hospital, but Stalin orders a subordinate not to injure the dentist otherwise. Id. at 652. Stalin's whim made conversation with the disgraced Kirov the equivalent of an offense, for which the dentist was severely punished; but Stalin's whim also saved the dentist from possible execution (perhaps because of his excellent dental work).

Along the same lines, Wolfgang Leonhard reports that, in the 1930 s in Moscow, an individual's mere presence in a café in which a foreign diplomat was sitting could possibly lead to criminal liability. "With a degree of imagination lon the part of the secret police], such a completely harmless occurrence could be expanded into participation in a conspiracy against Stalin." See Wolfgang Leonhard, Die Revolution entläßt ihre Kinder (1990) at 51-52.

Similar dangers were also clearly presented by Nazi legislation: 
But this important justification of the non-retroactivity principle may not be implicated in the border guards cases. Even if the nonretroactivity principle were disregarded for the border guards (and other GDR officials), this resolution would be limited to actions that occurred under a political system that has now irrevocably vanished. Accordingly, these cases could be seen as clearly distinguishable from the continued application of the non-retroactivity principle to contemporary citizens of the Federal Republic. As a result, disregarding the principle for GDR officials would presumably not create any great sense of terror or insecurity in contemporary German society-east or west. ${ }^{54}$

It might be necessary, therefore, to inquire whether other justifications of the non-retroactivity principle apply in these cases. Indeed, there seem principally to be two: First, there seems to be a sense of unfairness or injustice to individuals if they live their lives, in a legal system that has rules, thinking that what they were doing is legal within those rules, and then later-retroactively-the rules are changed, so that what they thought was legal when they were acting turns out to be illegal (unless, of course, one or more of arguments (1) through (6) are applicable). Perhaps one can say that is the case with many of the border guards.

Second, there is a problem of consistency within the western political and legal system. The Federal Republic has always argued that it is extending the rule of law over an eastern area that was governed by something in the nature of an injustice-regime or $U n$ rechtsstaat. There may seem to be some hypocrisy, then, if an important element of that extension includes a series of prosecutions in which one of the central principles of the rule of law-the principle of non-retroactivity-is not observed.55

Punishable is whoever commits a deed which the law declares to be punishable or which according to the basic idea of a penal code and healthy popular sentiment is worthy of punishment. If there is no penal law which directly applies to the deed, such shall be punished according to the law whose basic idea best applies thereto.

Gesetz zur Änderung des Strafgesetzbuchs, of 28 June 1935, § 2, translated in Ott \& Buob, "Did Legal Positivism Render German Jurists Defenceless during the Third Reich?," 2 Social and Legal Studies 91, 101 (1993).

54. Cf., e.g., Jaspers, supra n. 8, at 41-42:

"Retroactive effect is only prohibited by Article 103 [of the Basic Law] when it is a question of crimes within the [present] legal order . . . . In contrast, retroactive effect is possible-even called for-with respect to the acts of the prior criminal state. Retroactive effect is illegal only within the totality of a [particular legal] order. . . There, it would create uncertainty and contradict the rule of law."

55. Cf. Pieroth, "Der Rechtsstaat und die Aufarbeitung der vor-rechtsstaatlichen Vergangenheit," 51 VVDStRL 91, 112 (1992): "Building the rule of law in the east must not contribute toward dismantling the rule of law in all of Germany." Moreover, if the non-retroactivity principle were simply disregarded for acts occurring under the GDR, this approach could furnish another source of grievance for many easterners in the aftermath of German unification. Such a resolution could be viewed as yet an- 
$* * *$

It may be that in their practical effects there is a substantial overlap among a number of these arguments, and the distinction between them is not always clearly maintained in judicial opinions and theoretical discussions. Yet, it seems important to try to maintain clear distinctions between these arguments since they rest on foundations that vary significantly from one argument to another. If one of the arguments is employed, particular difficulties may have to be overcome that may not be present in another-apparently closely related-form of argument.

In any final evaluation of the strength of these various arguments, it seems to me important to recur to some sort of general understanding of what one is undertaking in thinking about these points. My own view is that the greatest clarity and candor are achieved when it is acknowledged that it is not really possible to go into past legal systems and change the principles of those legal systems for the purpose of achieving a particular result today. A legal system is an arrangement made in a particular society, for good or for ill. In the same way that one should not be allowed to rearrange history at will, one should not be able to rearrange or change the principles of the legal system that existed in the past and no longer exists. To do so is to assert that something was true that was not in fact true.

It may of course not always be possible to determine precisely what the applicable rules and principles of a particular past regime were, or what result those principles would have yielded in any particular case. Yet in most of the arguments that are used in the border guards cases-and similar cases-to rearrange or reinterpret the nature of the GDR legal system, a result is reached that we know was not the case under the legal understanding of the past regime. In many instances it is easier to know what was not the case, than to say precisely what the case was. ${ }^{56}$

In this way, I think that any argument that seeks to impose a different interpretation on a prior legal system than the one accepted within that system itself involves the creation of obfuscating fictions and should be rejected. Accordingly, we should certainly reject any argument such as that set forth in (5), through which the German courts have argued that the GDR legal system should be interpreted according to principles that indeed might be drawn from certain (partial) texts that existed then, but certainly formed no part of prevailing GDR interpretations then. Similarly, we should also reject

other way in which citizens of the former GDR were being treated as second-class citizens.

56. For discussion of this point in a related context, see Kaufmann, supra n. 11, at 83, citing Karl Popper, Logik der Forschung (1989). 
arguments such as (3) and (probably) (4) which state that certain overriding principles of law-whether of natural law (3) or international law (4) - overrode the positive law at the time. Of course, if the past legal system actually permitted this form of overriding, it would be permissible for us to invoke this procedure now; but that is generally not the case in dictatorial legal systems such as that of the GDR. It seems to me to be no more legitimate to argue that the principles of a past legal system were overridden then-if the internal law did not allow such overriding-than to impute any other principles to that legal system if those principles were not accepted at the time. A possible modification of this position, however, might arise if principles of international law made clear even then (as argued in the Nuremberg Judgment) that those principles overrode domestic law at the time. Yet, as discussed above, such a conclusion probably does not seem warranted in the border guards cases.

Argument (2) is somewhat more acceptable, at least theoretically. This argument asserts that the principle of retroactivity should be disregarded now because, under the historical circumstances as they existed then, the officials of the prior regime knew that their actions were in an important sense wrong or that, with respect to these actions, the principle of retroactivity might well not be preserved in the future. This argument does not require changing history by imputing principles to a prior legal system that were not actually in effect then. But it may require very difficult judgments of historical fact about what the prior officials actually believed, and also whether their belief in some other goals (such as furthering socialism, as they thought) may have outweighed or obviated in their minds any sense of guilt, or whether they really knew or suspected that they would eventually be brought to account. I would thus be inclined also to reject arguments of this kind-not because they are illegitimate, but rather because of the historical difficulties involved in determining whether they should be accepted in any particular case.

In my opinion, a more candid and persuasive argument is (1), the "strong" Radbruch argument. This is an argument that does not require the fictional re-interpretation of the nature of past legal systems, but candidly acknowledges that there are values that, under some circumstances, are more important than the non-retroactivity principle. This is an argument that focuses on the principles of a contemporary legal system, the legal system in which the courts and other commentators are currently functioning, and in my opinion involves the most candid understanding and exposition of the values that go into making the particular decision. ${ }^{57}$ Yet there are other

57. Cf. Hart, "Positivism and the Separation of Law and Morals," 71 Harv. L. Rev. $593,618-21(1958)$. 
problems with the use of this argument in the specific context of the GDR. First, under German constitutional law, the use of the "strong" Radbruch formula to remove a defense that existed under the law of the GDR would seem to violate Article 103(2) GG-at least without a constitutional amendment. ${ }^{58}$ Second, and more generally, it is not at all clear to me that the actions, such as those taken at the GDR border, are sufficiently comparable to the actions of the Nazi regime to permit overriding of this nature under this argument. Radbruch himself quite possibly would not have envisioned the use of this argument in these circumstances.

Another possibility is argument (7)(b) which asserts that, in the special circumstances of German unification, the retroactivity principle is not particularly important-totally apart from any countervailing arguments of justice, such as those endorsed in the Radbruch formula. Even though it seems clear that the GDR had a legal system, disregarding the retroactivity principle in the specific context of German unification would almost certainly not create the sense of insecurity and terror against which it is the core function of the nonretroactivity principle to guard. Yet the principle also fundamentally acknowledges the unfairness of disregarding past expectations, and that interest might nonetheless be sufficient to preserve the principle even in these circumstances. In addition, as some argue, it might be contradictory to extend the "Rechtsstaat" over the east, while simultaneously disregarding one of its central principles.

Finally, I would like to say a word about argument (6), the argument that certain actions were so extreme that they would not even in the past have been acknowledged to be protected by the earlier legal system. It seems clear beyond real argument that certain actions would have been considered by everyone within the former legal system actually to have violated the law of that system (even though for "reasons of state" or other reasons they were not prosecuted)such as the killing by a border guard of an unarmed person who had attempted to escape but was subsequently immobilized. I think present punishment is clearly permissible under these conditions. These kinds of prosecutions do not involve any real rearrangement or reinterpretation of the previous legal system and, at least under some circumstances, they seem fairly easy to determine. Indeed, given skepticism even about the use of argument (1), the strong Radbruch argument, in the case of the GDR - and given uncertainties about whether the retroactivity principle can be disregarded in the context of German unification without undue unfairness and possible hypocrisy-it seems quite possible to me that only the cases that fall under

58. See, e.g., Pieroth, supra n. 55, at 103-04. Yet the Constitutional Court has apparently taken a different view. 95 BVerfGE 96. 
argument (6) should now be subject to prosecution in the German courts.

\section{The Case of the Higher Officials: Should the Results Be Different?}

The discussion up to this point has focused on the culpability of the border guards themselves, and the argument has expressed some skepticism about whether, in most cases, there is a persuasive justification for finding the border guards guilty. Yet, even so, a question naturally arises about whether the higher GDR officials should be judged according to a more stringent standard. Perhaps these officials should bear criminal responsibility, even if it is concluded that the guards themselves should not.

Interestingly, however, the German courts do not always draw a clear distinction between the illegality of the acts of the border guards and those of the higher officials. Rather, in the German courts, findings of the higher officials' guilt have often depended upon the same underlying statutory construction that resulted in the criminal responsibility of the guards themselves. Indeed, in the BGH, the most difficult theoretical questions relating to Article 103(2), and the problem of possibly retroactive punishment, were resolved in the cases of the individual border guards - before the higher officials were even tried. ${ }^{59}$ Perhaps most important, in many instances the higher officials were not convicted of totally independent offenses, but rather for participation or complicity in the acts of the guards; therefore their convictions were not clearly separable from the illegality of the actions of the border guards..$^{60}$ Accordingly, under that technique, serious doubts about the illegality of the acts of the border guards could also lead to serious doubts about the illegality of the acts of the higher officials: it might be difficult to argue that the higher officials could be punishable even though the border guards were not.

Yet in some instances-primarily in the case of fatal injuries caused by land-mines-the offenses of the higher officials may have been independent of those of the guards themselves. ${ }^{61}$ Moreover, the question of whether the higher officials might be found criminally responsible, even when the guards were not, deserves more general consideration. Accordingly, it will be useful to review the seven argu-

59. See 39 BGHSt 1; Wesel, supra n. 21, at 34 .

60. In the National Defense Council and Politbüro cases, a total of six high GDR officials were convicted of complicity or indirect participation (mittelbare Täterschaft)

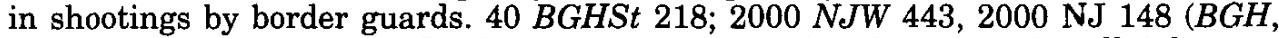
Decision of Nov. 8,1999 ). In the process of sentencing, however, the officials were treated with considerably greater severity than the guards. See Quint, supra n. 4, at $323-25$; see also $n .62$, infra.

61. See 40 BGHSt 218. 
ments for criminal liability-discussed in Section II-for the purpose of deciding whether doubts about the efficacy of those arguments in the case of the border guards might be mitigated or removed in the case of the higher officials. My conclusion on this point is that there may be some distinctions, but they are probably not clear or important enough to justify significantly different results in the cases of the higher officials.

At the outset of the discussion, it is important to distinguish this inquiry from another possible inquiry that is not at issue. If the underlying argument were that the border guards should be absolved on the grounds of the superior orders defense, it would certainly make sense to draw a distinction between the guards, as recipients of the orders, and the higher officials as givers of the orders. But, although the border guards did raise the defense of superior orders at trialalmost always without success-the arguments examined in Section II did not involve that defense. Rather, the discussion focused on the question of whether the guards' acts themselves were illegal and expressed some doubt that any of the seven arguments were sufficient to establish that illegality-except in a small number of extreme cases. In contrast, the claim of superior orders is generally raised as a defense with respect to acts that have already been held illegal; if one finds that the guards' acts were not illegal, then there is no need for a defense of superior orders and that defense does not come into play. ${ }^{62}$

Let us then make our way through the seven arguments to determine whether it might be possible to find that the acts of the higher GDR officials were illegal even if the acts of the border guards were not illegal. First, it is important to discard the arguments in which there is clearly no difference between border guards and higher officials. In argument (5), for example, the BGH argues that the GDR Border Law of 1982-which appears to provide a defense for many uses of deadly force by the border guards-should be given a narrowing construction that would result in a finding that the actions of the border guards were often actually illegal. This entire discussion turns on the interpretation of a statute that applies equally to the border guards and to the higher officials as participants in the criminal acts of the guards themselves. Accordingly, it seems difficult to employ this argument in a manner that would distinguish between the roles of the guards and the higher officials-that is, to argue that the same exculpatory statute should be construed broadly to absolve the acts of the border guards but should be.construed narrowly to

62. The responsibility of the higher officials in giving orders, however, did play a significant role in the process of sentencing, after the finding of illegality and guilt. See $95 B V \operatorname{lor} G E$ at 143 . For a case in which a border guard's defense of superior orders was accepted, under unusual circumstances, see 42 BGHSt 356. 
criminalize the acts of the higher officials. Under this argument, therefore, there seems to be no way to argue that the acts of the higher officials are illegal if the acts of the border guards are not. ${ }^{63}$

Perhaps a more significant difference between the border guards and the higher officials might arise in the context of argument (2)the argument that the defendants felt a sense of guilt for their acts or knew that, with respect to those acts, the non-retroactivity principle might not be preserved. Certainly the higher officials were in a better position to know that other countries considered their actions reprehensible, and that they might face punishment at some future point. Yet even in these cases, the question of whether a specific official possessed an actual sense of guilt-as well as the extent to which the individual had lost a reasonable reliance on the maintenance of the non-retroactivity principle- still presents serious factual issues that may make satisfactory inquiry difficult in the individual case.

In applying the two forms of the Radbruch formula-arguments (1) and (3)-there might also be a distinction between the border guards and the higher officials. The higher officials bore some responsibility for the deadly border regime overall-and therefore may have borne some responsibility for numerous killings-while the guards themselves were lower-level participants in the border regime and generally each individual defendant was responsible only for a single death. Yet Radbruch appeared to believe that successful invocation of the principle would require a degree of evil approaching that of the Nazi regime. Viewed in that light, the differences between the higher officials and the border guards do not seem to be so compelling. Even the high GDR officials do not appear to have had anything like the genocidal intent of the Nazi actors, and certainly they were not responsible for the millions of deaths that fall to the account of the Nazi regime. Yet if, on balance, a distinction is to be drawn between the border guards and the higher officials, it would seem best to do so under the "strong" Radbruch principle (argument 1)-by concluding that even if the degree of evil in the border guards' acts was not enough to outweigh the principle of non-retroactivity, the greater degree of evil in the acts of the higher officials was sufficient to do so. Here as above, I believe that the use of the "strong" Radbruch principle furnishes the most candid method of approaching these problems.

With respect to argument (4)-the argument that international law criminalized the actions at the time they were committed-there may not be a significant distinction between the guards and the officials. The question of whether the killings at the border fell into the category of international law crimes-principally genocide, torture, and crimes against humanity-will probably be answered in the same way regardless of whether the defendants are the guards or the

63. See Wesel, supra n. 21, at 43. 
higher officials. Of course, if international crimes were found to have been committed, there could be some defenses available to the guards alone. ${ }^{64}$ But if, as seems likely, the killings at the border do not rise to the level of international criminal offenses-or at least did not do so at the time they were committed-that conclusion would seem to apply across the board to all defendants.

A special problem is posed by argument (6), involving cases in which particularly murderous border guards clearly went beyond the defense provided by statutory law-for example by shooting a prisoner who had already surrendered. This argument for criminality might seem to apply only to the border guards themselves-individuals who actually fired weapons at immobilized prisoners-and not to the higher officials, the "desk-perpetrators". or Schreibtischtäter. Paradoxically, therefore, it might seem that this argument could impose criminal responsibility on the lower echelon border guards but not on the higher-level superiors. This conclusion, however, might not be inevitable. If, for example, a border guard general or other official urged or ordered guards to use deadly force beyond the statutory justification, that official might also be criminally liable in cases in which excessive force was actually used as a result. Moreover, as noted above, there is the complex question of the placing of land mines along the East German border (principally outside of Berlin), actions that may not have been authorized by statute. Here, the higher officials probably bear sole responsibility. A central question in this connection is the legal effect that should be attributed to nonstatutory sources of GDR law, such as votes of the National Defense Council purporting to authorize the practice. It has been asserted by some that the placement of these mines lacked effective legal authority; but this conclusion may not be clear under GDR law.

Finally, the general question posed by argument (7)-whether the entire non-retroactivity principle might be disregarded in connection with German unification-takes on a rather different form in the case of high government officials. Perhaps disregarding the non-retroactivity principle for official GDR actions might not result in widespread terror or insecurity in Germany today; yet it might still be thought unfair to disturb the reliance of the low-level border guards in the defense provided by the legal regime that existed at the time. In contrast, however, it might not seem so unfair to disregard the non-retroactivity principle with respect to the persons who actually made the law. Indeed, in this connection it might be useful to draw a distinction between those officials who played a significant role in actually making the law, and those officials who did not. Officials who

64. For example, if the shootings were found to constitute crimes against humanity based on a policy of political discrimination, it is conceivable that only the higher officials might have had the requisite knowledge of the particular policy in question. 
could not realistically have affected the law-such as some of the mid-level military officials who were not high enough to be in the inner-most political circles-might have the same kind of reliance in the framework of the legal structure as the lower-level military officials, the border guards.

But what about the highest political officials who might actually have had the power to require repeal of the statute-and thus to do away with the defense provided by the Border Law-or those who might have issued an order to the military that deadly force should no longer be used at the border?65 ${ }^{65}$ course, even these officials might argue that the border regime was required by the Soviet Union and that they really had no choice in the matter. But let us accept the conclusions of the German courts that, while the Soviet Union may have required that the border be closed, significant choices about the implementation of the border regime were left to the East German government. 66 Yet, even so, it is not entirely clear that there should be a difference for the high officials here. These officials still relied on the authoritativeness of the GDR legal structure as such, even though they may have been the persons empowered at the moment to change the legal rules. Perhaps even these officials should be entitled to that reliance unless one of the other possible argumentssuch as Radbruch's formula (arguments 1 and 3), a sense of guilt (argument 2), criminalization under rules of international law (argument 4), or clear criminality under GDR law (argument 6)-removes any existing defense. Moreover, the argument that the rule of law cannot be convincingly established by disregarding the rule of law applies in these cases as well.

Perhaps there may be some circumstances in which these arguments would permit penalization of the higher officials of the GDR even when the border guards might not be punishable. But these arguments seem difficult to make in most cases, and they often lack the particularly convincing quality that we would ordinarily like to see for criminalization.

Perhaps, overall, these arguments lead to the conclusion that it is not always a preferable course to criminalize reprehensible and dictatorial actions without some clear statement of their criminality at the time the acts were committed-and that revisions and extensions of international criminal law represent the best avenue for this approach. ${ }^{67}$ Indeed, there may be one final lesson to be learned from these cases-and other instances of the prosecution of "regime crimi-

65. According to recent information from the Stasi files, such an order actually seems to have been issued in spring 1989. See Frankfurter Allgemeine Zeitung, Feb. 2,1999 , p. 14 .

66. See LG Berlin, Decision of Sept. 16, 1993, 1994 NJ 210, 211; 95 BVerfGE at 138.

67. Cf., e.g., Gornig, supra n. 27, at 14. 
nality" in other countries in the last decade. These cases suggest that a careful review of international human rights documents should be undertaken with a view toward extending the scope of international criminality, in carefully selected areas, through a clear statement of prohibitions constituting crimes against humanity. Such a course of action would not only mitigate problems of retroactivity; it would also give unmistakable warning to future dictators of what kinds of acts could give rise to criminal liability in the future. With the emergence of an international criminal court, such a co-ordinated effort might seem more readily possible now than in the past.

Yet the definitions of crimes against humanity and related provisions in the present "Rome Statute" of the International Criminal Court suggest that further work is necessary on this score. ${ }^{68}$ Article 7 of the Rome Statute, which defines crimes against humanity, does not specifically refer to the use of deadly force to keep persons from leaving a country, in order to enforce a policy-like that of the GDRthrough which egress is rarely allowed. Nor does it make any specific reference to Articles 12 and 6 or other provisions of the International Covenant on Civil and Political Rights, whose intentional violation might be defined to constitute a crime against humanity.

Rather, under Article 7, crimes against humanity require "a widespread or systematic attack directed against any civilian population,"69 and it is not clear whether the use of deadly force at the border, to enforce a prohibition against flight, qualifies as an "attack" under this provision. Indeed, the concept of "attack" may well require a more aggressive initiative by the perpetrators, and it might not cover what is in effect a series of reactions under the guise of law enforcement - even when undertaken by a dictatorial regime. The Preparatory Commission for the International Criminal Court has recently issued its "Finalized draft text of the Elements of Crimes"-a document intended to clarify and lend specificity to the general provisions of the Rome Statute. 70 But the draft "Elements" do not specifically cover problems such as those raised by the cases of the GDR border guards. The Rome Charter, therefore, provides a general framework, but it does not answer more specific questions such as those posed by the cases of the border guards and the higher GDR officials. Certainly, a more concerted effort to resolve these and simi-

68. See Rome Statute of the International Criminal Court, U.N. Doc. A/CONF. 183/9(1998). On the Statute, see generally Sadat \& Carden, "The New International Criminal Court: An Uneasy Revolution," 88 Geo. L.J. 381 (2000).

69. Rome Statute, art. 7(1). Under art. 7(2)(a), “Attack directed against any civilian population' means a course of conduct involving the multiple commission of acts [such as murder, extermination, enslavement, torture, etc.] against any civilian population, pursuant to or in furtherance of a State or organizational policy to commit such attack."

70. U.N. Doc. PCNICC/2000/INF/3/Add.2, 6 July 2000. 
lar points would be important for a clearer understanding of these problems in the future. 